\title{
The Impact of SARS-CoV-2 Infection on Blood Coagulation and Fibrinolytic Pathways: A Review of Prothrombotic Changes Caused by COVID-19
}

\author{
Mehran Bahraini, $\mathrm{MSc}^{1} \quad$ Akbar Dorgalaleh, $\mathrm{PhD}^{1}$ \\ ${ }^{1}$ Department of Hematology and Blood Transfusion, School of Allied \\ Medicine, Iran University of Medical Sciences, Tehran, Iran \\ Semin Thromb Hemost 2022;48:19-30.
}

\begin{abstract}
Address for correspondence Mehran Bahraini, MSc, Department of Hematology and Blood Transfusion, School of Allied Medicine, Iran University of Medical Sciences, Tehran 1345634651, Iran (e-mail: mehranbahraini70@gmail.com).
\end{abstract}

\begin{abstract}
The cardinal pathology of coronavirus disease 2019 (COVID-19) is a primary infection of pulmonary tract cells by severe acute respiratory syndrome coronavirus 2 , provoking a local inflammatory response, often accompanied by cytokine storm and acute respiratory distress syndrome, especially in patients with severe disease. Systemic propagation of the disease may associate with thrombotic events, including deep vein thrombosis, pulmonary embolism, and thrombotic microangiopathy, which are important causes of morbidity and mortality in patients with COVID-19. This narrative review describes current knowledge of the pathophysiological mechanisms of COVID-19-associated coagulopathy, with focus on prothrombotic changes in hemostatic mediators, including plasma levels of clotting factors, natural anticoagulants, components of fibrinolytic system, and platelets. It will also highlight the central role of endothelial cells in COVID-19-associated coagulopathy. This narrative review discusses

Keywords

- SARS-CoV-2

- COVID-19

- coagulopathy

- thrombosis also potential therapeutic strategies for managing thrombotic complications. Awareness by medical experts of contributors to the pathogenesis of thrombotic events in COVID-19 is imperative to develop therapeutics not limited to regular anticoagulants. Instituting cooperation among medical personnel and researchers may lessen this novel virus' impact now, and in the event of recurrence.
\end{abstract}

The latest formidable hazard to global health is the advancing outbreak of severe acute respiratory syndrome coronavirus 2 (SARS-CoV-2), the novel virus responsible for coronavirus disease-19 (COVID-19), identified in December 2019 in Wuhan, China. Three months after the advent of COVID-19, the Director General of the World Health Organization announced that COVID-19 had become a global pandemic. ${ }^{1}$ At the time of writing, this outbreak is the gravest adversity worldwide, with nearly 200 million infected patients and more than 4 million deaths as of July 27, 2021. ${ }^{2}$

COVID-19 shows a broad spectrum of clinical manifestations, varying from asymptomatic, or mild, to upper respiratory tract signs, multiple organ dysfunction, cytokine storm, thrombotic complications manifested in most severe cases, and finally death. ${ }^{3}$ Fever, dry cough, dyspnea, and myalgia are the most common manifestations, followed by viral pneumonia and type 1 respiratory failure in 10 to $15 \%$ of cases. Around a third of patients require intensive care unit (ICU) admission for acute respiratory distress syndrome (ARDS), occasionally with multiorgan failure. ${ }^{4-6}$

SARS-CoV-2 mostly uses the body's angiotensin-converting enzyme-2 (ACE-2) as a receptor for entering the host cells. In addition to ACE-2, SARS-CoV-2 may require transmembrane protease serine 2 (TMPRSS2) and basigin (CD147) to infect cells, as well as entering the cells by a microparticlebearing pathway. ${ }^{7,8}$ There is also some evidence indicating that coronaviruses tend to interact with acetylated sialic acid residues presented copiously on the membrane proteins of published online October 25, 2021
Issue Theme Maintaining Hemostasis and Preventing Thrombosis in COVID-19-Part III; Guest Editors: Emmanuel J. Favaloro, PhD, FFSc (RCPA) and Giuseppi Lippi, MD (c) 2021. Thieme. All rights reserved. Thieme Medical Publishers, Inc., 333 Seventh Avenue, 18th Floor, New York, NY 10001, USA
DOI https://doi.org/ 10.1055/s-0041-1736166. ISSN 0094-6176. 
megakaryocytes and endothelial cells. ${ }^{9,10}$ This narrative review deals with what is known about COVID-19-associated coagulopathy, focusing on current knowledge of alterations in blood coagulation and fibrinolysis mediators following SARS-CoV-2 infection and their association with disease mortality, especially in severely affected patients.

\section{COVID-19 as a Novel Risk Factor of Thrombosis}

A plethora of evidence, retrieved from a large variety of studies covering this pandemic, has highlighted a large incidence of hemostatic derangements in the form of hypercoagulable and hypofibrinolytic states, mostly in critically ill patients receiving intensive care support..$^{11-14}$ The virus does not seem to have innate prothrombotic effects; instead, the hemostatic disturbances are most likely a consequence of the profound hyperinflammatory response and endotheliopathy, even if a direct platelet-activating effect cannot be ruled out. $^{15,16}$ The prime etiology of morbidity and mortality in these patients is the synchronized activation of inflammatory responses and coagulation pathways (known as thromboinflammation). ${ }^{17,18}$ The early clinical findings reported from Wuhan, China, indicated that patients with the severe form of disease suffered from acute lung disturbance and hypoxia. ${ }^{19-22}$ Laboratory findings also showed that a large number of hospitalized patients have plasma hypercoagulability with significantly high levels of D-dimer, and mild prolongation of prothrombin time (PT) with slight thrombocytopenia. ${ }^{23,24}$ The complementary reports from other countries demonstrated that extremely ill patients receiving intensive care support experienced thrombotic events, including deep vein thrombosis (DVT) and pulmonary embolism (PE). ${ }^{25-30}$ Autopsy findings corroborated these findings, with reports of deteriorating PE following DVT in the lower extremities, and frequent reports of platelet-rich clots in the small arteries and capillaries of the lung. ${ }^{31-35} \mathrm{PE}$ has been the most common thrombotic event, followed by DVT and arterial thrombosis. ${ }^{36,37}$

Fundamental aspects of the underlying mechanisms of COVID-19-associated hemostatic disorders have not been precisely characterized. However, it is well appreciated that this condition results from a severe inflammatory response to the virus, one that is conceptualized in the literature as "thromboinflammation." 17 Thromboinflammation was also confirmed in SARS and Middle East respiratory syndrome (MERS), both of which are caused by coronaviruses. ${ }^{38}$ Since the respiratory tract is the primary gateway for coronavirus, the inflammatory process initially involves the alveoli, progresses to cytokine storm, and triggers a localized hemostatic dysfunction with ensuing formation of microthrombi in the pulmonary vasculature. Autopsy findings support the notion of lung-originating coagulopathy in COVID-19 patients. $^{32,39}$ In patients with systemic inflammatory response syndrome, consequent to more severe illness, this condition might be followed by a generalized coagulopathy in the gastrointestinal tract or lower extremity, or as coronary or cerebrovascular ischemia. ${ }^{40-43}$ Based on the high potential risk of thrombotic events, interim guidance from the International Society on Thrombosis and Haemostasis recommends thromboprophylaxis with heparin in all hospitalized patients, as long as anticoagulation does not impose additional bleeding risk. ${ }^{35,44}$ When the diagnosis of thromboembolism is confirmed, anticoagulation with a therapeutic dose is recommended. However, major thrombotic events still occur, even in patients undergoing anticoagulation.

\section{Pathophysiology of COVID-19-Associated Coagulopathy}

Generalized infection, similar to what is seen in bacteria- or virus-induced sepsis, causes systemic inflammation and activation of clotting pathways, which can lead to sepsisinduced coagulopathy, a state known as thromboinflammation. ${ }^{45}$ Vascular endothelial cells seem to be a hotspot in the cross-talk between inflammation and coagulation. The collaboration between coagulation pathways and endothelial cells is crucial for adequate hemostasis. ${ }^{46}$ ARDS, frequently seen following sepsis-induced multiorgan failure, is indicated by disordered endothelial-cell integrity and alveolar damage, with fibrin being deposited inside the pulmonary vasculature and alveolar cavity. ${ }^{47,48}$ In a SARS-CoV-2 infection, endotheliopathy primarily occurs in the lung; respiratory endothelial cells are directly infected by the virus via interaction of its spike glycoprotein and the host ACE-2 receptor, which is copiously expressed on endothelial cells. ${ }^{42}$ After the virus has entered the respiratory tract cells, innate immune cells present pattern recognition receptors (PRRs) to identify exogenous pathogen-associated molecular patterns. ${ }^{49}$ Endogenous damage-associated molecular patterns created by damaged cells are also consistently recognized by PRRs. All three factors of the old concept of Virchow's triad seem to be involved in the pathogenesis of thrombotic events in COVID-19 (-Fig. 1).

Pathophysiological mechanisms of COVID-19-associated coagulopathy comprise multiple systems and their interactions (-Fig. 2). Endothelial damage causes subendothelial collagen exposure and tissue factor (TF) decryption. TF release into the plasma along with von Willebrand factor (VWF) leads to activation and propagation of the coagulation cascade and platelet adhesion pathways. ${ }^{50,51}$ Circulatory markers of endothelial damage, including VWF, soluble thrombomodulin, plasminogen activator inhibitor-1 (PAI-1), and angiopoietin 2, have been correlated to increased mortality in patients with COVID-19. ${ }^{52-54}$ Therefore, innate inflammatory response and coagulation-cascade activation are triggered primarily in the lung and create localized microthrombi in the alveolar vasculature, which are generalized in the severe form of the disease. Inflammatory cytokines, as interleukin 6 (IL-6) and multiple acute-phase reactants, can cause endotheliitis. Alternative- and lectincomplement pathway activation also has been reported to exacerbate inflammation and endotheliitis. The renin-aldosterone-angiotensin system (RAAS) is involved through the interaction of ACE2, in host cells, and the virus spike protein. ${ }^{55}$ Moreover, angiotensin II upregulates PAI-1 expression 


\section{COVID-19 and Virchow's triad}

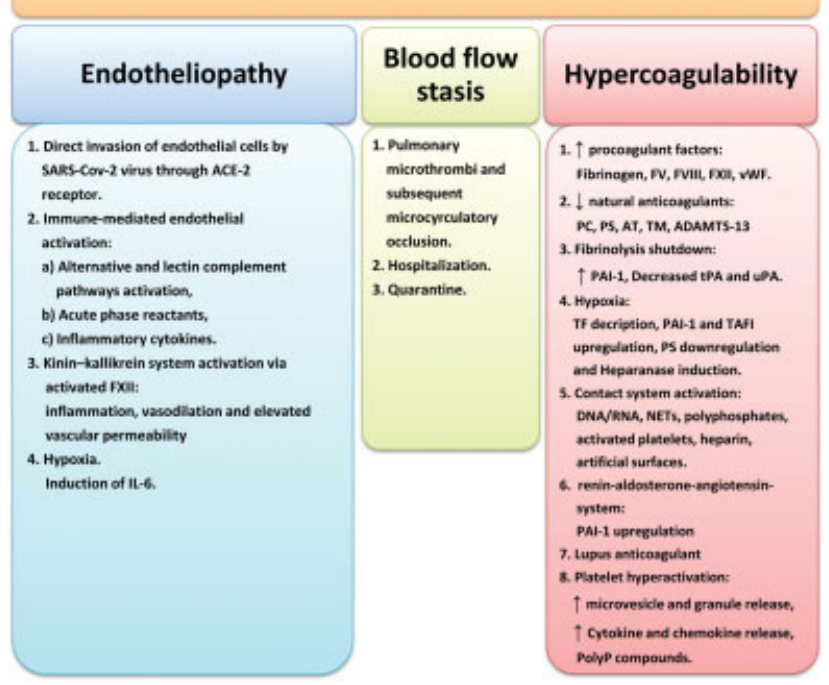

Fig. 1 Pathogenesis of COVID-19-associated coagulopathy. Attachment and entrance of SARS-Cov-2 virus by endothelial's ACE-2 receptor causes endotheliitis. Immune system hyperactivation, including alternative and lectin complement pathway activation, release of acute-phase reactants and cytokine storm further induce endotheliitis. Kinin-kallikrein system activation, with endpoint product of bradykinin, results in vasodilation and vascular permeability, and subsequent edema in many organs, as well as inflammation. Pulmonary occlusive microthrombosis decelerates microcirculation in the lung. Immobility follows hospitalization and quarantine. Elevated clotting factors, presence of lupus anticoagulant, reduced natural anticoagulants, along with fibrinolysis shutdown, create a hypercoagulable environment. In addition to inflammation and heparinization resistance via induction of IL-6 and heparanase respectively, hypoxia potentiates hypercoagulable and hypofibrinolytic conditions. Contact system activation occurs via negatively charged natural or artificial materials. The Reninaldosterone-angiotensin system further potentiates the hypofibrinolytic state. Pathophysiological platelet hyperactivation includes elevated microvesicle, granule, cytokine, and chemokine release. Excretion of polyphosphate (polyP) compounds by activated platelet leads to activation of FXII. ACE-2, angiotensin-converting enzyme 2; ADAMTS-13, a disintegrin and metalloprotease with a thrombospondin type 1 motif, member 13; AT, antithrombin; F, factor; IL-6, interleukin-6; NETs, neutrophil extracellular traps; PAl-1, plasminogen activator inhibitor-1; PC, protein C; PS, protein S; SARS-Cov-2, severe acute respiratory syndrome coronavirus 2; TAFI, thrombin-activatable fibrinolysis inhibitor; TF, tissue factor; TM, thrombomodulin; tPA, tissue plasminogen activator; uPA, urokinase plasminogen activator; VWF, von Willebrand factor.

in endothelial cells, ${ }^{56-58}$ and the release of PAI-1 from their $\alpha$-granules. ${ }^{59}$ Thus, deregulated RAAS may create a prothrombotic condition in patients by increasing PAI-1 levels. The contact system activation and the kallikrein-kinin systems are incorporated in the pathophysiology of COVID-19-associated coagulopathy and hyperinflammation. ${ }^{60,61}$ Negatively charged surfaces such as nucleic acids, heparin, polyphosphate compounds, activated platelets, neutrophil extracellular traps, and artificial surfaces could localize factor XII (FXII), plasma prekallikrein (PK), and highmolecular-weight kininogen (HMWK) close together, whereupon reciprocal activation of FXII and PK occurs. ${ }^{62}$ FXIIa triggers the intrinsic coagulation pathway and kallikrein drives inflammation by cleaving HMWK to bradykinin (BK) causing consequent vascular permeability. ${ }^{62}$ An additional significant contributing mechanism to the coagulopathy is severe hypoxia due to COVID-19-associated lung injury. ${ }^{63}$ Under severe hypoxic conditions, hypoxia-inducible factor-1 (HIF-1) upregulates PAI-1 and TF while downregulating protein $S^{64-66}$ (-Fig. 2).

HIF-2 also drives PAI-1 and suppresses TF pathway inhibitor. ${ }^{67,68}$ Hypoxia also suppresses thrombomodulin expression on endothelial cells, with subsequent antithrombin inefficiency. ${ }^{69-71}$ One of the notable explanations of anticoagulation inefficiency with heparin, in the management of COVID-19 patients with thrombosis, may be the fact that hypoxia induces heparanase activity. ${ }^{72}$ Obesity is another risk factor of hypercoagulability, as obese patients have shown hypercoagulable and hypofibrinolytic changes, including elevated levels of FVII, FVIII, VWF, TF, fibrinogen, PAI-1, and thrombin-activatable fibrinolysis inhibitor (TAFI). ${ }^{73-75}$ A role for lupus anticoagulant and antiphospholipid antibodies has been suggested for pathogenesis of COVID-19-associated coagulopathy. ${ }^{52,76-80}$ In severely infected patients, immobility under conditions of quarantine or hospitalization is another predisposing factor of thrombosis. ${ }^{81,82}$ Modification of the equilibrium between clot formation and degradation in favor of hypercoagulability and hypofibrinolysis, impaired endothelial function, platelet hyperactivation, and excessive immune response are emerging as major contributors to the thrombotic complications. Thus, using a multipurposed therapeutic approach beyond the regular anticoagulants can better prepare for fighting the disease ( $\mathbf{-}$ Table $\mathbf{1}$ ). Of all proposed pathophysiological mechanisms of COVID-19-associated coagulopathy, this review will focus on prothrombotic blood coagulation and fibrinolytic changes in patients severely infected with SARS-CoV-2.

\section{Clotting Factors}

Increased levels of plasma clotting factors are reflective of hypercoagulability in COVID-19 patients. There are several studies regarding changes in the plasma levels of their clotting factors. Most reported results on levels of fibrinogen, VWF antigen, and factor VIII (FVIII) activity. A study assessing 24 patients admitted to the ICU showed increased fibrinogen levels in all patients, markedly increased FVIII activity (up to $460 \mathrm{U} / \mathrm{dL}$ ), and VWF antigen in $11(48 \%)$ patients. ${ }^{83}$ While these findings were not consistent with acute disseminated intravascular coagulation (DIC), they supported the association of hypercoagulability with inflammation. ${ }^{83}$ A case series of 10 severe COVID-19 cases showed a marked increase in FVIII activity and plasma fibrinogen concentration, but none developed symptomatic venous thromboembolism (VTE) ${ }^{84}$ Significant immunohistochemical hyper-expression of FVIII has been highlighted in an autopsy study on lung specimens of two patients. ${ }^{85}$ Another study, on 102 patients, indicated significant increases in plasma levels of fibrinogen, VWF, and FVIII in those needing respiratory support, compared with those with minimal or no respiratory support. ${ }^{86}$ 
A

B

C

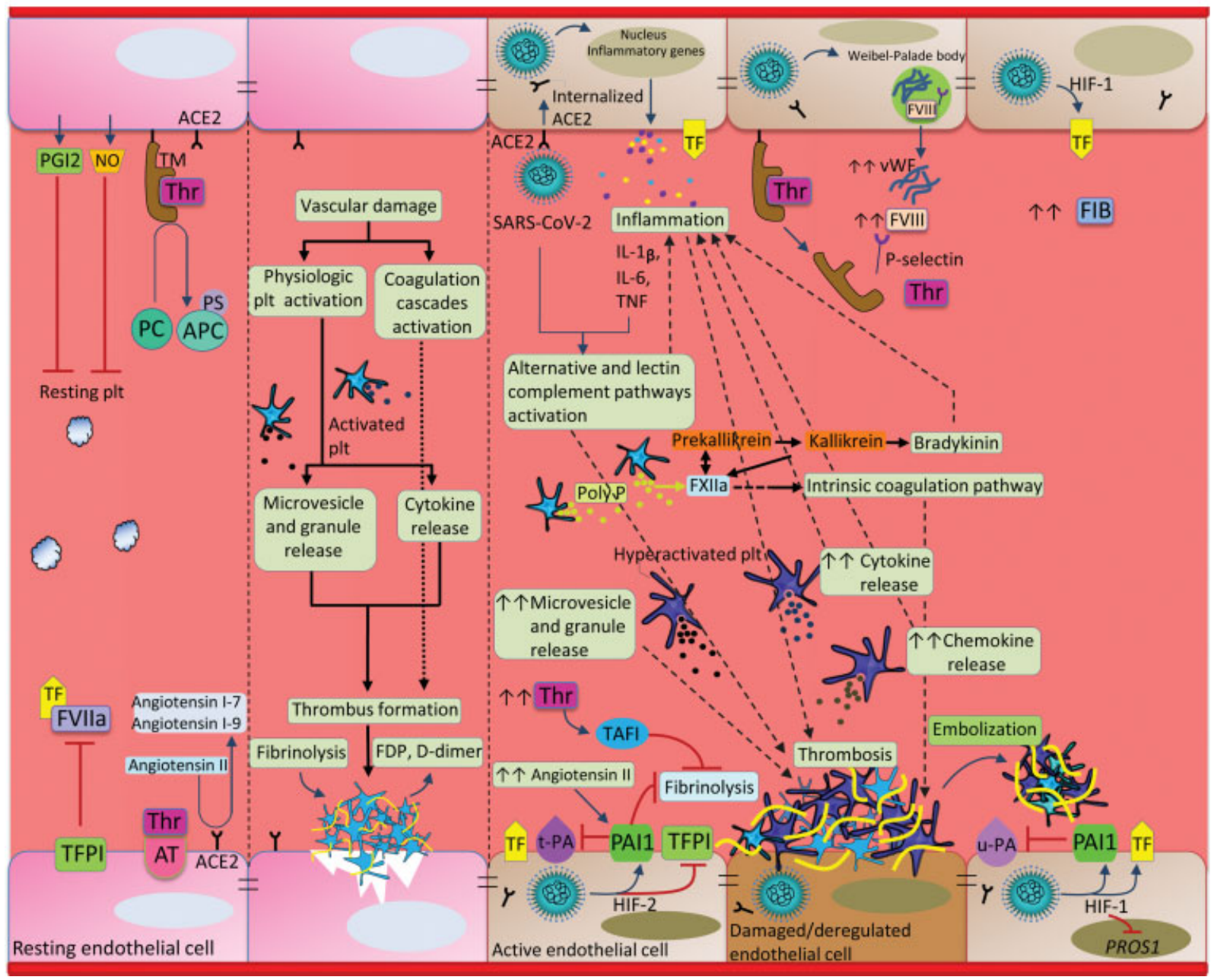

Fig. 2 COVID-19 pathogenesis. (A) In the absence of damage or pathogen, the endothelial cells and platelets maintain their resting modes and stay away from each other, hemostasis continues unaffected. Resting endothelial cells produce natural anti-inflammatories and anticoagulants, including nitric oxide (NO), prostaglandin $\mathrm{I}_{2}\left(\mathrm{PGI}_{2}\right)$, activated protein $\mathrm{C}(\mathrm{APC})$, thrombomodulin (TM), antithrombin (AT), and tissue factor pathway inhibitor (TFPI). The angiotensin-converting enzyme 2 (ACE2) receptor on the endothelial cell surface is typically involved in the unimpaired renin-aldosterone-angiotensin system through converting angiotensin II to angiotensin 1-9 and angiotensin 1-7, thus preventing the accumulation of angiotensin II. (B) In the presence of vascular damage, physiological hemostatic mechanisms are triggered until blood loss is completely stopped and the clot is dissolved. (C) Direct invasion by severe acute respiratory syndrome coronavirus 2 (SARS-CoV-2) of the endothelial cell, via the ACE-2 receptor, causes activation of the endothelium, characterized by elevated circulatory levels of von Willebrand factor (VWF), factor VIII (FVIII), soluble TM, and plasminogen activator inhibitor 1 (PAI1). The inflammatory process related to COVID-19 that augments immune cell responses, production of inflammatory cytokines (such as IL-1 $\beta$, IL-6, and TNF), and activation of the complement pathway further influences the endothelium and mediates endothelial damage and dysfunction. Inflammation reduces the bioavailability of $\mathrm{PGI}_{2}$ and NO, leading to endothelial damage. In the hyperinflammatory and hypoxic condition, pathological hyperactivation of platelets and coagulation cascades, combined with endothelial dysfunction, lead to thrombus formation. The contact system activation via negatively charged surfaces, like polyphosphate (polyP) compounds, combined with kallikrein-kinin systems, accentuates the hypercoagulability and inflammatory condition through the production of activated FXII (FXIla) and bradykinin, respectively. The hypoxia-inducible factor-1 (HIF-1) and -2 (HIF-2) upregulate PAI-1 and TF, as they downregulate the protein S gene (PROS1) and TFPI, leading to hypercoagulability and hypofibrinolysis. The PAI1 levels are elevated by accumulated levels of circulatory angiotensin II when ACE2 is internalized, following SARS-CoV-2 infection, and could not proteolyse the angiotensin II. The increased thrombin (Thr) generation drives thrombin-activatable fibrinolysis inhibitor (TAFI) to suppress PAl1. Despite the increased profibrinolytic factors of tissue (tPA) and urokinase (uPA) plasminogen activators, overwhelming levels of PAI1 and TAFI create the net result of fibrinolysis shutdown and lead to embolization of the platelet-rich fibrin clot. IL, interleukin; TNF, tissue factor necrosis.

Certain alveolar endothelial cells produce FVIII, a prothrombotic acute-phase reactant and marker of endothelial cell activation, as are fibrinogen and VWF, all three of which are frequently reported to be increased in the plasma. These data may support the notion that endotheliitis and subsequent pulmonary microthrombosis originate in the alveoli and are caused by SARS-CoV-2. ${ }^{87,88}$ Moreover, relatively low levels of ADAMTS13 (a disintegrin and metalloprotease with a thrombospondin type 1 motif, member 13) in plasma in association with the high VWF antigen may lead to microangiopathic changes in critically ill patients. ${ }^{89}$ von Meijenfeldt and colleagues compared hemostatic changes during hospitalization and at their follow-up 4 months after discharge. Factor V (FV), VWF, and fibrinogen were increased in 
Table 1 Major contributors to COVID-19 pathogenesis and their related potential therapeutic approaches

\begin{tabular}{|c|c|c|}
\hline Pathology & Laboratory features & Potential therapeutics \\
\hline Coagulopathy & $\begin{array}{l}\uparrow \text { D-dimer, } \\
\uparrow \text { Fibrinogen, factor VIII, von } \\
\text { Willebrand factor, tissue factor } \\
\uparrow \text { PAI- } 1 \text { and tPA } \\
\uparrow \text { Clot lysis resistance } \\
\downarrow \text { Natural anticoagulants } \\
\uparrow \text { Thrombin generation potential } \\
\uparrow \text { Plasma kallikrein }\end{array}$ & $\begin{array}{l}\text { Heparin (prophylactic or therapeutic doses) } \\
\text { Fibrinolytic therapy with alteplase (tPA) or } \\
\text { nebulized recombinant t-PA } \\
\text { Wild-type activated protein C } \\
\text { Wild-type protein S } \\
\text { Recombinant antithrombin } \\
\text { Recombinant thrombomodulin } \\
\text { Plasma kallikrein inhibitors (lanadelumab and } \\
\text { ecallantide) }\end{array}$ \\
\hline Endotheliopathy & $\begin{array}{l}\uparrow \text { Factor VIII and von Willebrand factor } \\
\text { Soluble thrombomodulin } \\
\uparrow \text { PAI- } 1 \\
\uparrow \text { Angiopoietin } 2\end{array}$ & $\begin{array}{l}\text { Prostacyclin therapy (iloprost, epoprostenol, } \\
\text { and treprostinil) } \\
\text { Inhaled nitric oxide } \\
\text { Phosphodiesterase } 3 \text { inhibitors (dipyridamole } \\
\text { and cilostazol) }\end{array}$ \\
\hline Thrombocytopathy & $\begin{array}{l}\text { Borderline thrombocytopenia } \\
\text { Platelet hyperactivation. }\end{array}$ & $\begin{array}{l}\text { Prostacyclin therapy } \\
\text { Inhaled nitric oxide } \\
\text { Phosphodiesterase } 3 \text { inhibitors } \\
\text { Aspirin } \\
\text { P2Y } 12 \text { inhibitors }\end{array}$ \\
\hline $\begin{array}{l}\text { Excessive immune } \\
\text { response and inflammation }\end{array}$ & $\begin{array}{l}\uparrow \text { Inflammatory markers (C- reactive protein, } \\
\text { erythrocyte sedimentation rate, and ferritin) } \\
\uparrow \text { Inflammatory cytokines (IL-1 } \beta \text {, IL-6, and TNF- } \alpha \text { ) } \\
\text { Macrophage activation, complement } \\
\text { system, and NETosis } \\
\uparrow \text { Bradykinin }\end{array}$ & $\begin{array}{l}\text { Dexamethasone } \\
\text { Tocilizumab (anti-IL-6) } \\
\text { Eculizumab (C5 blocker) } \\
\text { Anakinra (anti-IL-1 } \beta \text { ) } \\
\text { Plasma exchange to reduce cytokine storm } \\
\text { Prostacyclin therapy } \\
\text { Inhaled nitric oxide } \\
\text { Recombinant 3K3A-APC mutant }{ }^{\mathrm{a}}\end{array}$ \\
\hline
\end{tabular}

Abbreviations: C5, complement component 5; COVID-19, coronavirus disease 2019; IL-1 $\beta$, interleukin-1 $\beta$; IL-6, interleukin-6; NETosis, neutrophil extracellular trap formation; P2Y 12, the adenosine diphosphate receptor on platelets; PAI-1, plasminogen activator inhibitor-1; TNF- $\alpha$, tumor necrosis factor $\alpha$; tPA, tissue plasminogen activator.

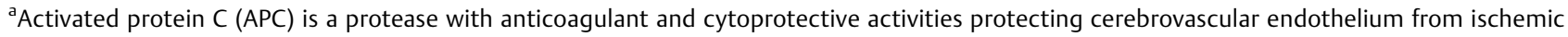
injury. 3K3A-APC, a modified APC, maintains its full cytoprotective and anti-inflammatory effects while it confers approximately $90 \%$ lower anticoagulant activity than wild-type APC.

patients during hospitalization, but normalized at the follow-up. Factor II (prothrombin) (FII) was significantly elevated at follow-up, compared with control and hospitalization levels. Thrombinography results showed considerably raised thrombin-generating potential at follow-up, but were not associated with elevated prothrombin. FVIII levels were elevated during hospitalization and remained significantly higher than levels found in healthy controls. This increase in FVIII suggests a continued hypercoagulable state in survivors. ${ }^{90}$ In a study on 20 critically ill patients admitted to ICU, two groups were studied, those who died within 24 hours after coagulation-profile sampling (terminal-stage group) and those who lived more than 3 days after sampling (nonterminal-stage group). In both groups FVIII activity was significantly higher than, and had approximately the same values as, the normal range. Other clotting factor activities including FII, FV, FVII, FIX, FX, FXI, and FXII remained in the normal range in both patient groups. In the terminal-stage group, FV and FVII activity was much lower than that in the nonterminal group. However, FV and FVII activities, confirmed by prolonged PT, were much lower in the terminal-stage group than in the nonterminal group. ${ }^{91}$ In a cohort of 102 severely ill hospitalized patients there was a marked elevation of FV activity (34-248 IU/dL, median $=150)$ compared with the control group $(22-161 \mathrm{IU} / \mathrm{dL}$, median $=105 ; p<0.001)$. FV activity was associated with the rate of VTE. Patients with elevated FV activity ( $>150$ $\mathrm{IU} / \mathrm{dL}$ ) experienced significantly higher rates of VTE than those with FV activity $\leq 150 \mathrm{IU} / \mathrm{dL}$ (33 vs. $13 \%$; $p=0.03$ ). The VTE rate was lower among anticoagulated COVID-19 patients ( $21 \%, n=91$ vs. $36 \%, n=11$ ) and those with increased FV activity, (30\%, $n=44$ vs. $60 \%, n=5$ ) when compared with nonanticoagulated. However, these differences were not statistically significant. These findings do suggest that FV deserves further investigation for VTE and anticoagulation therapies. In the former study, fibrinogen and FVIII activity were also significantly higher; FX activity was slightly (or marginally) higher. Patients with concomitant increases in FV and FVIII activity had higher VTE rates than those with normal activity $(p=0.048) .{ }^{92}$ FXII is probably the most involved, directly connected to the inflammatory responses via the BK-forming kallikrein-kinin system. Bronchoalveolar lavage fluids from 54 ARDS patients in a case-control study revealed FXII to be upregulated, with higher levels in ARDS fatalities, and was positively associated with tumor necrosis factor- $\alpha$ levels. ${ }^{93}$ One of the autopsy findings has been the 
accumulation of FXII in patients' lung tissue, with immunofluorescence analysis indicating FXII activation within the respiratory vascular walls and in clot-rich alveolar cavities. FXII is located at the central position of the contact activation system, with pivotal roles in triggering inflammatory responses, complement system, and coagulation cascade. Hence, FXII could be considered a valuable pharmacological target in the management of severely ill patients. ${ }^{62}$

\section{Natural Anticoagulants}

\section{Protein S}

Given the fact that protein S plays a dual role in anticoagulation and immunosuppression, it is hypothesized that a secondary deficiency of protein S, following SARS-CoV-2 infection, is strongly implicated in the underlying mechanisms of COVID-19-associated coagulopathy and cytokine storm. Unfortunately, in the context of COVID-19, there is scant empirical research into protein $S$ level changes over the course of the disease. A study investigating the effect of baseline protein $S$ activity of 91 patients, with survival as the main outcome, revealed protein $S$ activity to be reduced in $65 \%$ of the patients; death was associated with lower activity of protein S (median 42 vs. $58 \%, p<0.001$ ). ${ }^{94}$ Another study showed a significant decrease in protein $S$ activity of patients compared with the control group. ${ }^{91}$ Two other studies reported protein $S$ activity slightly below the normal range. ${ }^{83,92}$ The available COVID-19 literature around the role of protein $\mathrm{S}$ in coagulopathy and hyperinflammation crosstalk is more hypothetical than experimental. Increased plasma level of protein S-regulatory protein C4BP, caused by proinflammatory responses, leads to unavailability of free protein $\mathrm{S}$ for anticoagulant activities. ${ }^{95}$ Development of autoantibody against protein $S$ during adaptive immune responses can cause protein $S$ insufficiency, as seen in varicella infection. ${ }^{96}$ As a common consequence of respiratory distress in gravely ill COVID-19 patients, hypoxia downregulates PROS1 gene expression. ${ }^{64}$ Increased expression of IL-6 in stroke patients was associated with decreased protein $S$ levels and a higher rate of VTE. ${ }^{97}$ IL-6, as an early sensitive and specific predictor of a severe course of COVID-19, ${ }^{19,98-101}$ also downregulates PROS1 gene expression. ${ }^{102}$ Recently proposed is the direct proteolysis of protein $\mathrm{S}$ by the virus via its own papain-like protease (PLpro). ${ }^{103}$ Endotheliopathy as a common consequence of COVID-19 infection can reduce protein $S$ levels, since endothelial cells are the major site of protein $S$ production. ${ }^{103}$ As the virus also affects two other sources of protein S synthesis or storage, platelets and hepatocytes, it can, theoretically, reduce the plasma level of protein S. ${ }^{103}$ Given the critical roles played by protein $\mathrm{S}$, it can potentially be considered as a therapeutic target in COVID-19 disease. However, whether secondary protein $\mathrm{S}$ deficiency causes both coagulopathy and hyperinflammation, for any reason, needs further investigation. More cohorts of patients are needed to determine whether protein S deficiency, if present, is itself a result of progressive, consumptive coagulopathy in a hyperinflammatory condition induced by the virus, and whether it exacerbates in- flammation. In a hyperinflammatory state caused by virusinduced sepsis, the coagulation cascades are activated and progress to the consumption of all hemostatic mediators (even anticoagulants like protein S), a pathologic condition termed DIC. Since protein S is itself an anti-inflammatory protein, its consumption (deficiency) can potentially exacerbate inflammation.

\section{Antithrombin}

Concerning the changes in plasma levels of antithrombin, a systematic review and meta-analysis of 471 patients calculated the weighted mean difference (WMD) of antithrombin levels in these patients with or without severe illness. ${ }^{104}$ It was shown that WMD of antithrombin levels in the gravely ill ( $n=197,41.8 \%$ ), compared with those with a milder course, was $-10 \mathrm{IU} / \mathrm{dL}$ (95\% confidence interval: -3 to $-17 \mathrm{IU} / \mathrm{dL}$; I2: $86 \%)$. This study indicated that antithrombin levels are significantly reduced in severe illness. ${ }^{104}$ Six cohorts showed antithrombin levels below the lower limit of the normal range, not in all, but in several their investigated subjects. ${ }^{83,84,91,105-107}$ One of them found body mass index (BMI) to be significantly higher in patients with lower antithrombin values and documented an inverse correlation between antithrombin values and BMI $(r$ : $-0.33 ; p=0.0179)$, suggesting that antithrombin may be the link between obesity and a poorer prognosis. ${ }^{107}$ Two other COVID-19 cohorts found antithrombin levels significantly lower in nonsurvivors than in survivors. ${ }^{107,108}$ Liao et al studied 308 patients retrospectively and found a significantly higher incidence of low antithrombin activity in critically ill and severely ill groups than in those with moderate disease. ${ }^{109}$ In another study, reduced antithrombin values have been reported to be associated with nephritis. ${ }^{110}$ However, five cohorts comparing the antithrombin activity between patients and a control group, and between ICU and non-ICU patients, showed that antithrombin values in most patients were within normal range, without any significant difference between the studied populations. ${ }^{11,30,52,92,111}$ Altogether, these findings suggest that SARS-CoV-2-induced acute antithrombin deficiency caused by consumptive coagulopathy, or reduced production due to acute inflammation, justifies inclusion of antithrombin measurements as essential in the routine laboratory measures for monitoring COVID-19 patients. $^{112}$

Antithrombin supplementation has also been a valuable measure for management of critically ill patients. ${ }^{108,113}$ However, it is yet unknown why the acute antithrombin deficiency occurs in only some patients. Unfractionated heparin (UFH) and low-molecular-weight heparin (LMWH), the two anticoagulants that are widely used in hospitals, require antithrombin to be efficacious. Another hypothesis posits that acute antithrombin deficiency may be responsible for inability to achieve an adequate anticoagulant effect following the usual doses of heparin therapy in some patients. ${ }^{114}$ A multicenter cohort study on 150 SARSCoV-2-infected patients evidenced thrombotic events in $43 \%$ of patients despite heparin therapy or prophylaxis. However, this reported failure of a response to heparin was not mechanistically related to antithrombin deficiency as the 
majority had normal or even high levels of antithrombin. ${ }^{30}$ Another cohort of 10 critically ill patients, who experienced thrombosis despite receiving prophylactic doses of LMWH, showed that all had reduced antithrombin levels. They were also nonresponders to the therapeutic doses of UFH. However, argatroban, a direct thrombin inhibitor that works independently of antithrombin, provided the patients with adequate anticoagulation. ${ }^{115}$ Anakli et al also found that antithrombin supplementation using fresh frozen plasma, in severely ill patients experiencing COVID-19-associated coagulopathy, improves the anticoagulant effect of UFH and LMWH without the need to elevate heparin dosage. ${ }^{108}$

\section{Fibrinolytic System}

The imbalance between profibrinolytic and antifibrinolytic factors leads to pathologically upregulated (hyper-) or downregulated (hypo-) fibrinolysis. Fibrinolysis shutdown/ fibrinolysis resistance, which refers to a state of hypofibrinolysis, seems to be one of the leading pathophysiological mechanisms of the hypercoagulable state in COVID-19 disease. Viscoelastic hemostatic assays using thromboelastography (TEG) or rotational thromboelastometry (ROTEM) has provided evidence (such as elevated maximum clot firmness [MCF] and reduced maximum lysis) that patients severely infected with SARSCoV-2 are in a hypofibrinolytic state. ${ }^{11,12,116-118}$ In addition, "complete fibrinolysis shutdown" (lysis at 30 minutes of $0 \%$ on TEG) has also been reported in $57 \%$ of severely ill patients $(n=44) .{ }^{118}$ A significant association between the hypofibrinolytic state and thrombotic complications was also evidenced by these studies. Moreover, the addition of exogenous tissue plasminogen activator ( $\mathrm{TPA}$ ) to the ROTEM sample of COVID-19 patients did not confer any sensitivity to the additive tPA. ${ }^{11,119-121}$ Finally, two studies demonstrated that ICU patients who received therapeutic anticoagulation had significantly higher MCF and clot lysis time than the control groups. ${ }^{122,123}$ The molecular mechanism of the hypofibrinolytic state in critical COVID-19 illness seems attributable primarily to the overexpression of PAI- 1 , the most potent antifibrinolytic mediator, from endothelial cells and activated platelets. ${ }^{124-126}$ However, it seems that elevated PAI-1 is perhaps not the only cause of hypofibrinolysis. Studies on patients with interstitial lung disease have also evidenced an increase of TAFI and PAI-3 (protein C inhibitor) in the alveolar space. ${ }^{127,128}$ Similar results were highlighted during the 2003 SARS-CoV epidemic. ${ }^{129,130}$ Today, significantly increased PAI-1 values have been found in multiple studies on patients with COVID-19, with some studies reporting values up to fourfold higher in COVID-19 patients compared with control groups. $^{123,131}$ This overload of PAI-1 in SARS-CoV-2 infection can be further aggravated by raised angiotensin II levels in the blood of patients with COVID-19, with PAI-1 levels being upregulated in the endothelial cells, resulting in elevated circulatory PAI-1 levels. ${ }^{56,58,123,127}$ Angiotensin 1-9 also activates platelets and stimulates the release of PAI- 1 from $\alpha$ granules. ${ }^{59}$ Moreover, several studies have found elevation, in the plasma levels, of tPA, urokinase plasminogen activator (uPA), and TAFI in patients suffering from the severe form of
COVID-19, ${ }^{11,132}$ demonstrating the variable effects of infection on the fibrinolytic system. It seems that the overexpression of PAI-1 and TAFI overwhelms the local profibrinolytic effects of elevated tPA and uPA levels. Hence, the net result of these changes is a hypofibrinolytic state.

\section{Platelets}

Thrombocytopenia has been reported in approximately 55\% of patients with SARS, ${ }^{133,134}$ which, together with leukopenia, was the predominant laboratory feature. ${ }^{135}$ The degree of thrombocytopenia and hypoxia was used as a prognostic model to estimate the mortality rate in the 2003 epidemic with an accuracy of $96.2 \% .{ }^{136}$ Similar studies corroborated these findings in SARSCoV. ${ }^{135,137-140}$ Thrombocytopenia and lymphopenia were introduced as a disease severity index and predictive factor of developing pneumonia and respiratory failure in MERS-CoV infection. ${ }^{141,142}$ Other studies also endorsed these observations in the MERS-CoV epidemic. ${ }^{143-145}$ A similar trend has been observed in SARS-CoV-2 infection; thrombocytopenia has been reported in 5 to $41.7 \%$ of patients, depending on disease severity, ${ }^{23,146-148}$ and a meta-analysis of 1,779 COVID-19 patients demonstrated that thrombocytopenia correlated with a more than fivefold elevated risk of grave sickness. ${ }^{149}$ Another metaanalysis of 7,613 patients demonstrated that the critically ill had a lower platelet count than those with nonsevere illness. ${ }^{150} \mathrm{~A}$ temporary downward trend of platelet count could be clinically indicative of an aggravating thrombotic condition during hospitalization. ${ }^{151}$ - Table 2 summarizes the changes in platelet indices in patients with COVID-19. Thrombocytopenia along with platelet hyperactivation (thrombocytopathy) contributes to the excessive thrombosis and deregulated immune response.

SARS-CoV-2-induced endothelial damage in the lung leads to platelet adhesion to the subendothelium of the pulmonary microvasculature via the aid of VWF's bridging function; subsequent platelet-rich thrombotic microangiopathy hinders viremic spread through the circulation. ${ }^{147,152}$ In patients affected with the severe form of COVID-19, elevated total levels and binding capacity of VWF, with concomitant mild thrombocytopenia, suggests that infection triggers the process of platelet thrombosis, thereby activating the coagulation cascade. Consumption of platelets during the early stages of pulmonary endothelial damage is followed by a compensatory response of the bone marrow to restore the circulatory platelet count. This rebound thrombocytosis is accompanied by production of larger (increased mean platelet volume) and younger (increased immature platelet fraction) platelets with higher hemostatic potential. ${ }^{146,153}$ Some pathophysiological mechanisms of virus-induced thrombocytopenia have been proposed so far, including generation of autoantibodies against platelets, viral invasion of the megakaryocytes via CD13 or CD66a, and endotheliitis-routed platelets and coagulation cascade activation with subsequent platelet consumption. ${ }^{154}$ SARS-CoV-2 also changes the gene expression pattern of platelets, such as elevation in the basal expression of P-selectin. ${ }^{155}$ The molecular basis of platelet hyperactivity seen in patients with COVID-19 may 
Table 2 Platelet indices changes in COVID-19 patients

\begin{tabular}{|l|l|l|}
\hline Parameters & In patients affected with SARS-Cov-2 & Reference \\
\hline Platelet count & $\begin{array}{l}\text { Usually normal, until the advanced stages, when it reduces to moderately low } \\
\text { levels. }\end{array}$ & 149,150 \\
\hline MPV & $\begin{array}{l}\text { Increased (at least in unwell patients with thrombocytopenia). } \\
\text { Correlates with a decline in average platelet count. } \\
\text { Can be used as an effective indicator of platelet activation and increased } \\
\text { thrombosis risk. }\end{array}$ & $158-160$ \\
\hline IPF & $\begin{array}{l}\text { Increased (at least in unwell patients with thrombocytopenia). } \\
\text { Effective indicators of platelet activation and increased thrombosis risk. } \\
\text { Predictor of a reduction in the total platelet count during coagulopathy. } \\
\text { Reticulated platelets may reflect an increased platelet turnover in the setting } \\
\text { of a normal platelet count and this aspect could be of critical importance in the } \\
\text { early diagnosis of COVID-19. }\end{array}$ & 158 \\
\hline PDW & $\begin{array}{l}\text { Increased (at least in unwell patients with thrombocytopenia). } \\
\text { A key marker of platelet activation in patients with COVID-19. } \\
\text { Increased in venous thrombosis as well as in several hypercoagulable states, } \\
\text { such as cardiovascular diseases. }\end{array}$ & 160 \\
\hline PLR & $\begin{array}{l}\text { Patients with severe COVID-19 have higher levels of PLR than patients with } \\
\text { nonsevere disease. In COVID-19, PLR may be used as separate prognostic } \\
\text { indicators of disease seriousness. }\end{array}$ & 161,162 \\
\hline MPR & A high MPR level is an independent risk factor for severe pneumonia. \\
\hline P-LCR & A high P-LCR is significantly associated with lower survival rates. & 163 \\
\hline
\end{tabular}

Abbreviations: IPF, immature platelet fraction; MPV, mean platelet volume; MRP, platelet mean volume/platelet count ratio; PDW, platelet distribution width; P-LCR, platelet larger cell ratio; PLR, platelet to lymphocyte ratio; SARS-CoV-2, severe acute respiratory syndrome coronavirus 2.

be associated with the increased MAPK pathway activation and thromboxane production. ${ }^{155}$

As the major and rapid compensators of platelet consumption or clearance, megakaryocytes possibly undergo pathological changes (megakaryocytopathy) during SARS-CoV-2 infection. One study revealed that the lung tissue of some patients with COVID-19 contains abnormal CD61+ megakaryocytes with nuclear hyperchromasia and atypia. ${ }^{39}$ A case series of autopsy studies showed that megakaryocytes are present in the heart, kidneys, and especially lungs of patients with COVID-19. ${ }^{156}$ Both studies have suggested that those megakaryocytes were actively producing platelets. However, the presence of these compensatory megakaryocytes, which possibly originated in the lungs, is inconsistent with the developing thrombocytopenia seen in some patients. A therapeutic application for antiplatelet drugs in patients has not yet been recommended for all patients. It is unclear whether targeting platelets during SARS-CoV-2 infection improves patient outcomes. Today, many randomized clinical trials are proposed on the use of prophylactic doses of antiplatelet agents in the management of patients with COVID-19 (NCT04365309, NCT04363840, NCT04410328; https://clinicaltrials.gov). However, in patients with mild thrombocytopenia, antiplatelet therapy would carry a greater risk of hemorrhage. ${ }^{157}$

\section{Conclusion}

COVID-19-associated coagulopathy is identified by a hypercoagulable state with a subsequent high rate of thrombotic microangiopathy, DVT and PE. Thrombotic events are the major cause of morbidity and mortality in extremely sick patients. The pathogenesis of COVID-19-associated thrombosis is likely to involve various cell types and elaborately interconnected processes including hemostasis, vascular integrity, and inflammation. It seems that endotheliopathy and thrombocytopathy may play a central role in the etiology of thrombotic microangiopathy in patients with COVID-19. Direct invasion of the endothelium and platelets by the virus can result in endotheliopathy and thrombocytopathy, respectively. These can also be due to the cellular response to the virus-induced inflammation, triggering immune cell response, complement activation, and cytokine storm. Although anticoagulation alone has yielded some satisfaction, we are still faced with dreadful thrombotic complications even in patients receiving anticoagulants. Thus, targeting a couple of main pathological processes with combinational therapeutic approaches, or treatment with pleiotropically acting drugs, is likely to be more efficacious than the approach of dealing exclusively with thrombosis in patients with COVID-19.

Conflict of Interest

None declared.

\section{Acknowledgment}

The authors highly appreciate Daisy Morant's and Alieh Fazeli's valuable contribution in improving the English language of the article. 


\section{References}

1 Sohrabi C, Alsafi Z, O'Neill N, et al. World Health Organization declares global emergency: a review of the 2019 novel coronavirus (COVID-19). Int J Surg 2020;76:71-76

2 Johns Hopkins University. COVID-19 Dashboard by the Center for Systems Science and Engineering (CSSE) at Johns Hopkins University (JHU). Accessed July 27, 2021 at: https://www.arcgis.com/apps/ dashboards/bda7594740fd40299423467b48e9ecf6

$3 \mathrm{Lu} \mathrm{H}$. Drug treatment options for the 2019-new coronavirus (2019-nCoV). Biosci Trends 2020;14(01):69-71

4 Rodriguez-Morales AJ, Cardona-Ospina JA, Gutiérrez-Ocampo E, et al; Latin American Network of Coronavirus Disease 2019COVID-19 Research (LANCOVID-19) Electronic address: https:// www.lancovid.org. Clinical, laboratory and imaging features of COVID-19: a systematic review and meta-analysis. Travel Med Infect Dis 2020;34:101623

5 Fernandes Valente Takeda C, Moura de Almeida M, Gonçalves de Aguiar Gomes R, et al. Case report: recurrent clinical symptoms of COVID-19 in healthcare professionals: a series of cases from Brazil. Am J Trop Med Hyg 2020;103(05):1993-1996

6 Alimohamadi Y, Sepandi M, Taghdir M, Hosamirudsari H. Determine the most common clinical symptoms in COVID-19 patients: a systematic review and meta-analysis. J Prev Med Hyg 2020;61(03):E304-E312

7 Zhou P, Yang XL, Wang XG, et al. A pneumonia outbreak associated with a new coronavirus of probable bat origin. Nature 2020; 579(7798):270-273

8 Hoffmann M, Kleine-Weber H, Schroeder S, et al. SARS-CoV-2 cell entry depends on ACE2 and TMPRSS2 and is blocked by a clinically proven protease inhibitor. Cell 2020;181(02):271.e8-280.e8

9 Tortorici MA, Walls AC, Lang Y, et al. Structural basis for human coronavirus attachment to sialic acid receptors. Nat Struct Mol Biol 2019;26(06):481-489

$10 \mathrm{Kim}$ C-H. SARS-CoV-2 evolutionary adaptation toward host entry and recognition of receptor O-Acetyl sialylation in virus-host interaction. Int J Mol Sci 2020;21(12):4549

11 Nougier C, Benoit R, Simon M, et al. Hypofibrinolytic state and high thrombin generation may play a major role in SARS-COV2 associated thrombosis. J Thromb Haemost 2020;18(09): 2215-2219

12 Bachler M, Bösch J, Stürzel DP, et al. Impaired fibrinolysis in critically ill COVID-19 patients. Br J Anaesth 2021;126(03): 590-598

13 Zanza C, Racca F, Longhitano Y, et al. Risk management and treatment of coagulation disorders related to COVID-19 infection. Int J Environ Res Public Health 2021;18(03):1268

14 Mitrovic M, Sabljic N, Cvetkovic Z, et al. Rotational thromboelastometry (ROTEM) profiling of COVID-19 patients. Platelets 2021; 32(05):690-696

15 Connors JM, Levy JH. COVID-19 and its implications for thrombosis and anticoagulation. Blood 2020;135(23):2033-2040

16 Greinacher A, Selleng K, Mayerle J, et al. Anti-platelet factor 4 antibodies causing VITT do not cross-react with SARS-CoV-2 spike protein. Blood 2021;6(03):22-29

17 Seitz R, Gürtler L, Schramm W. Thromboinflammation in COVID-19: can $\alpha_{2}$-macroglobulin help to control the fire? J Thromb Haemost 2021;19(02):351-354

18 Lippi G, Sanchis-Gomar F, Favaloro EJ, Lavie CJ, Henry BM. Coronavirus disease 2019-associated coagulopathy. Mayo Clin Proc 2021;96(01):203-217

19 Huang C, Wang Y, Li X, et al. Clinical features of patients infected with 2019 novel coronavirus in Wuhan, China. Lancet 2020;395 (10223):497-506

20 Chen N, Zhou M, Dong X, et al. Epidemiological and clinical characteristics of 99 cases of 2019 novel coronavirus pneumonia in Wuhan, China: a descriptive study. Lancet 2020;395 (10223):507-513
21 Wang D, Hu B, Hu C, et al. Clinical characteristics of 138 hospitalized patients with 2019 novel coronavirus-infected pneumonia in Wuhan, China. JAMA 2020;323(11):1061-1069

$22 \mathrm{Wu}$ C, Chen X, Cai Y, et al. Risk factors associated with acute respiratory distress syndrome and death in patients with coronavirus disease 2019 pneumonia in Wuhan, China. JAMA Intern Med 2020;180(07):934-943

23 Guan WJ, Ni ZY, Hu Y, et al; China Medical Treatment Expert Group for Covid-19. Clinical characteristics of coronavirus disease 2019 in China. N Engl J Med 2020;382(18):1708-1720

24 Zhou F, Yu T, Du R, et al. Clinical course and risk factors for mortality of adult inpatients with COVID-19 in Wuhan, China: a retrospective cohort study. Lancet 2020;395(10229):1054-1062

25 Cui S, Chen S, Li X, Liu S, Wang F. Prevalence of venous thromboembolism in patients with severe novel coronavirus pneumonia. J Thromb Haemost 2020;18(06):1421-1424

26 Ren B, Yan F, Deng Z, et al. Extremely high incidence of lower extremity deep venous thrombosis in 48 patients with severe COVID-19 in Wuhan. Circulation 2020;142(02):181-183

27 Zhang L, Feng X, Zhang D, et al. Deep vein thrombosis in hospitalized patients with COVID-19 in Wuhan, China: prevalence, risk factors, and outcome. Circulation 2020;142(02):114-128

28 Middeldorp S, Coppens M, van Haaps TF, et al. Incidence of venous thromboembolism in hospitalized patients with COVID-19. J Thromb Haemost 2020;18(08):1995-2002

29 Poissy J, Goutay J, Caplan M, et al; Lille ICU Haemostasis COVID-19 Group. Pulmonary embolism in patients with COVID-19: awareness of an increased prevalence. Circulation 2020;142(02):184-186

30 Helms J, Tacquard C, Severac F, et al; CRICS TRIGGERSEP Group (Clinical Research in Intensive Care and Sepsis Trial Group for Global Evaluation and Research in Sepsis) High risk of thrombosis in patients with severe SARS-CoV-2 infection: a multicenter prospective cohort study. Intensive Care Med 2020;46(06): 1089-1098

31 Wichmann D, Sperhake J-P, Lütgehetmann M, et al. Autopsy findings and venous thromboembolism in patients with COVID19: a prospective cohort study. Ann Intern Med 2020;173(04): 268-277

32 Dolhnikoff M, Duarte-Neto AN, de Almeida Monteiro RA, et al. Pathological evidence of pulmonary thrombotic phenomena in severe COVID-19. J Thromb Haemost 2020;18(06):1517-1519

33 Carsana L, Sonzogni A, Nasr A, et al. Pulmonary post-mortem findings in a series of COVID-19 cases from northern Italy: a twocentre descriptive study. Lancet Infect Dis 2020;20(10): $1135-1140$

34 Menter T, Haslbauer JD, Nienhold R, et al. Postmortem examination of COVID-19 patients reveals diffuse alveolar damage with severe capillary congestion and variegated findings in lungs and other organs suggesting vascular dysfunction. Histopathology 2020;77(02):198-209

35 Ackermann M, Verleden SE, Kuehnel M, et al. Pulmonary vascular endothelialitis, thrombosis, and angiogenesis in Covid-19. N Engl J Med 2020;383(02):120-128

36 Al Raizah A, Al Askar A, Shaheen N, et al. High rate of bleeding and arterial thrombosis in COVID-19: Saudi multicenter study. Thromb J 2021;19(01):13

37 Ozsu S, Gunay E, Konstantinides SV. A review of venous thromboembolism in COVID-19: a clinical perspective. Clin Respir J 2021;15(05):506-512

38 Benvenuto D, Giovanetti M, Ciccozzi A, Spoto S, Angeletti S, Ciccozzi M. The 2019-new coronavirus epidemic: evidence for virus evolution. J Med Virol 2020;92(04):455-459

39 Fox SE, Akmatbekov A, Harbert JL, Li G, Quincy Brown J, Vander Heide RS. Pulmonary and cardiac pathology in African American patients with COVID-19: an autopsy series from New Orleans. Lancet Respir Med 2020;8(07):681-686 
40 Connors JM, Levy JH. Thromboinflammation and the hypercoagulability of COVID-19. J Thromb Haemost 2020;18(07): 1559-1561

41 van Langevelde K, Srámek A, Vincken PW, van Rooden J-K, Rosendaal FR, Cannegieter SC. Finding the origin of pulmonary emboli with a total-body magnetic resonance direct thrombus imaging technique. Haematologica 2013;98(02):309-315

42 Varga Z, Flammer AJ, Steiger P, et al. Endothelial cell infection and endotheliitis in COVID-19. Lancet 2020;395(10234):1417-1418

43 Guo T, Fan Y, Chen M, et al. Cardiovascular implications of fatal outcomes of patients with coronavirus disease 2019 (COVID-19). JAMA Cardiol 2020;5(07):811-818

44 Barrett CD, Moore HB, Yaffe MB, Moore EE. ISTH interim guidance on recognition and management of coagulopathy in COVID19: a comment. J Thromb Haemost 2020;18(08):2060-2063

45 Meziani F, Gando S, Vincent J-L. Should all patients with sepsis receive anticoagulation? Yes. Intensive Care Med 2017; 43:452-454

46 Liao JK. Linking endothelial dysfunction with endothelial cell activation. J Clin Invest 2013;123(02):540-541

47 Finigan JH. The coagulation system and pulmonary endothelial function in acute lung injury. Microvasc Res 2009;77(01):35-38

48 Sharp C, Millar AB, Medford AR. Advances in understanding of the pathogenesis of acute respiratory distress syndrome. Respiration 2015;89(05):420-434

49 Han S, Mallampalli RK. The acute respiratory distress syndrome: from mechanism to translation. J Immunol 2015;194(03):855-860

50 Levi M, van der Poll T, Ten Cate H. Tissue factor in infection and severe inflammation. Semin Thromb Hemost 2006;32(01): 33-39

51 Sebag SC, Bastarache JA, Ware LB. Therapeutic modulation of coagulation and fibrinolysis in acute lung injury and the acute respiratory distress syndrome. Curr Pharm Biotechnol 2011;12 (09):1481-1496

52 Goshua G, Pine AB, Meizlish ML, et al. Endotheliopathy in COVID19-associated coagulopathy: evidence from a single-centre, cross-sectional study. Lancet Haematol 2020;7(08):e575-e582

53 Meizlish ML, Pine AB, Goshua G, et al. Circulating markers of angiogenesis and endotheliopathy in COVID-19. medRxiv 2020; 15(03):45-64

54 Favaloro EJ, Henry BM, Lippi G. Increased VWF and decreased ADAMTS-13 in COVID-19: creating a milieu for (micro)thrombosis. Semin Thromb Hemost 2021;47(04):400-418

55 Dalan R, Bornstein SR, El-Armouche A, et al. The ACE-2 in COVID-19: foe or friend? Horm Metab Res 2020;52(05):257-263

56 Vaughan DE, Lazos SA, Tong K. Angiotensin II regulates the expression of plasminogen activator inhibitor- 1 in cultured endothelial cells. A potential link between the renin-angiotensin system and thrombosis. J Clin Invest 1995;95(03):995-1001

57 Vaughan DE. Endothelial function, fibrinolysis, and angiotensinconverting enzyme inhibition. Clin Cardiol 1997;20(11, Suppl 2): II-34-II-37

58 Nakamura S, Nakamura I, Ma L, Vaughan DE, Fogo AB. Plasminogen activator inhibitor-1 expression is regulated by the angiotensin type 1 receptor in vivo. Kidney Int 2000;58(01):251-259

59 Mogielnicki A, Kramkowski K, Hermanowicz JM, Leszczynska A, Przyborowski K, Buczko W. Angiotensin-(1-9) enhances stasisinduced venous thrombosis in the rat because of the impairment of fibrinolysis. J Renin Angiotensin Aldosterone Syst 2014;15 (01):13-21

60 Meini S, Zanichelli A, Sbrojavacca R, et al. Understanding the pathophysiology of COVID-19: could the contact system be the key? Front Immunol 2020;11:2014

61 Urwyler P, Moser S, Charitos P, et al. Treatment of COVID-19 with conestat alfa, a regulator of the complement, contact activation and Kallikrein-Kinin system. Front Immunol 2020;11:2072

62 Spence JD, de Freitas GR, Pettigrew LC, et al. Mechanisms of stroke in COVID-19. Cerebrovasc Dis 2020;49(04):451-458
63 Thachil J. Hypoxia-an overlooked trigger for thrombosis in COVID-19 and other critically ill patients. J Thromb Haemost 2020;18(11):3109-3110

64 Pilli VS, Datta A, Afreen S, Catalano D, Szabo G, Majumder R. Hypoxia downregulates protein S expression. Blood 2018;132 (04):452-455

65 Prchal JT. Hypoxia and thrombosis. Blood 2018;132(04): 348-349

66 Wang GL, Jiang B-H, Rue EA, Semenza GL. Hypoxia-inducible factor 1 is a basic-helix-loop-helix-PAS heterodimer regulated by cellular 02 tension. Proc Natl Acad Sci U S A 1995;92(12): 5510-5514

67 Görlach A, Diebold I, Schini-Kerth VB, et al. Thrombin activates the hypoxia-inducible factor-1 signaling pathway in vascular smooth muscle cells: role of the p22(phox)-containing NADPH oxidase. Circ Res 2001;89(01):47-54

68 Gupta N, Zhao Y-Y, Evans CE. The stimulation of thrombosis by hypoxia. Thromb Res 2019;181:77-83

69 Ogawa S, Gerlach H, Esposito C, Pasagian-Macaulay A, Brett J, Stern D. Hypoxia modulates the barrier and coagulant function of cultured bovine endothelium. Increased monolayer permeability and induction of procoagulant properties. J Clin Invest 1990;85(04):1090-1098

70 Ogawa S, Shreeniwas R, Brett J, Clauss M, Furie M, Stern DM. The effect of hypoxia on capillary endothelial cell function: modulation of barrier and coagulant function. Br J Haematol 1990;75 (04):517-524

71 Ogawa S, Shreeniwas R, Butura C, Brett J, Stern DM. Modulation of endothelial function by hypoxia: perturbation of barrier and anticoagulant function, and induction of a novel factor $\mathrm{X}$ activator. Adv Exp Med Biol 1990;281:303-312

72 Rivara S, Milazzo FM, Giannini G. Heparanase: a rainbow pharmacological target associated to multiple pathologies including rare diseases. Future Med Chem 2016;8(06):647-680

73 Faber DR, de Groot PG, Visseren FL. Role of adipose tissue in haemostasis, coagulation and fibrinolysis. Obes Rev 2009;10 (05):554-563

74 Sattar N, McInnes IB, McMurray JJV. Obesity is a risk factor for severe COVID-19 infection: multiple potential mechanisms. Circulation 2020;142(01):4-6

75 Vilahur G, Ben-Aicha S, Badimon L. New insights into the role of adipose tissue in thrombosis. Cardiovasc Res 2017;113(09): 1046-1054

76 Beyrouti R, Adams ME, Benjamin L, et al. Characteristics of ischaemic stroke associated with COVID-19. J Neurol Neurosurg Psychiatry 2020;91(08):889-891

77 Harzallah I, Debliquis A, Drénou B. Lupus anticoagulant is frequent in patients with Covid-19: response to reply. J Thromb Haemost 2020;12(04):34-50

78 Oxley TJ, Mocco J, Majidi S, et al. Large-vessel stroke as a presenting feature of Covid-19 in the young. N Engl J Med 2020;382(20):e60

79 Favaloro EJ, Henry BM, Lippi G. COVID-19 and antiphospholipid antibodies: time for a reality check? Semin Thromb Hemost 2021 (e-pub ahead of print). Doi: 10.1055/s-0041-1728832

80 Favaloro EJ, Henry BM, Lippi G. Is lupus anticoagulant a significant feature of COVID-19? A critical appraisal of the literature. Semin Thromb Hemost 2021 (e-pub ahead of print). Doi: 10.1055/s-0041-1729856

81 Vannini L, Llanos Gómez JM, Quijada-Fumero A, Fernández Pérez AB, Hernández Afonso JS. COVID-19 quarantine and acute pulmonary embolism. Rev Esp Cardiol (Engl Ed) 2020;73(08): 680-682

82 Ali A, Omore I, Asare L, Gabani M, Riaz M. Seated-immobility thromboembolism syndrome complicating coronavirus disease 2019 outbreak quarantine. Chest 2020;158(04):A1614

83 Panigada M, Bottino N, Tagliabue P, et al. Hypercoagulability of COVID-19 patients in intensive care unit: a report of 
thromboelastography findings and other parameters of hemostasis. J Thromb Haemost 2020;18(07):1738-1742

84 Tabatabai A, Rabin J, Menaker J, et al. Factor VIII and functional protein $C$ activity in critically ill patients with coronavirus disease 2019: a case series. A A Pract 2020;14(07):e01236

85 Cipolloni L, Sessa F, Bertozzi G, et al. Preliminary post-mortem COVID-19 evidence of endothelial injury and factor VIII hyperexpression. Diagnostics (Basel) 2020;10(08):575

86 von Meijenfeldt FA, Havervall S, Adelmeijer J, et al. Prothrombotic changes in patients with COVID-19 are associated with disease severity and mortality. Res Pract Thromb Haemost 2020; 5(01):132-141

87 Shovlin CL, Angus G, Manning RA, et al. Endothelial cell processing and alternatively spliced transcripts of factor VIII: potential implications for coagulation cascades and pulmonary hypertension. PLoS One 2010;5(02):e9154

88 Jacquemin M, Neyrinck A, Hermanns MI, et al. FVIII production by human lung microvascular endothelial cells. Blood 2006;108 (02):515-517

89 Huisman A, Beun R, Sikma M, Westerink J, Kusadasi N. Involvement of ADAMTS13 and von Willebrand factor in thromboembolic events in patients infected with SARS-CoV-2. Int J Lab Hematol 2020;42(05):e211-e212

90 von Meijenfeldt FA, Havervall S, Adelmeijer J, et al. Sustained prothrombotic changes in COVID-19 patients 4 months after hospital discharge. Blood Adv 2021;5(03):756-759

91 Zhang Y, Cao W, Jiang W, et al. Profile of natural anticoagulant, coagulant factor and anti-phospholipid antibody in critically ill COVID-19 patients. J Thromb Thrombolysis 2020;50(03): 580-586

92 Stefely JA, Christensen BB, Gogakos T, et al. Marked factor V activity elevation in severe COVID-19 is associated with venous thromboembolism. Am J Hematol 2020;95(12):1522-1530

93 Hess R, Wujak L, Hesse C, et al. Coagulation factor XII regulates inflammatory responses in human lungs. Thromb Haemost 2017;117(10):1896-1907

94 Stoichitoiu LE, Pinte L, Balea MI, Nedelcu V, Badea C, Baicus C. Anticoagulant protein $S$ in COVID-19: low activity, and associated with outcome. Rom J Intern Med 2020;58(04):251-258

95 van de Poel RH, Meijers JC, Bouma BN. Interaction between protein $\mathrm{S}$ and complement $\mathrm{C} 4 \mathrm{~b}$-binding protein (C4BP). Affinity studies using chimeras containing $c 4 \mathrm{bp} \beta$-chain short consensus repeats. J Biol Chem 1999;274(21):15144-15150

96 Khan R, Yasmeen A, Pandey AK, Al Saffar K, Narayanan SR. Cerebral venous thrombosis and acute pulmonary embolism following varicella infection. Eur J Case Rep Intern Med 2019;6 (10):001171

97 Vila N, Reverter JC, Yagüe J, Chamorro A. Interaction between interleukin- 6 and the natural anticoagulant system in acute stroke. J Interferon Cytokine Res 2000;20(03):325-329

98 Conti P, Ronconi G, Caraffa A, et al. Induction of pro-inflammatory cytokines (IL- 1 and IL-6) and lung inflammation by Coronavirus-19 (COVI-19 or SARS-CoV-2): anti-inflammatory strategies. J Biol Regul Homeost Agents 2020;34(02):327-331

99 McGonagle D, Sharif K, O'Regan A, Bridgewood C. The role of cytokines including interleukin-6 in COVID-19 induced pneumonia and macrophage activation syndrome-like disease. Autoimmun Rev 2020;19(06):102537

100 Chen X, Zhao B, Qu Y, et al. Detectable serum SARS-CoV-2 viral load (RNAaemia) is closely correlated with drastically elevated interleukin 6 (IL-6) level in critically ill COVID-19 patients. Clin Infect Dis 2020;45(05):155-163

101 Ulhaq ZS, Soraya GV. Interleukin-6 as a potential biomarker of COVID-19 progression. Med Mal Infect 2020;50(04):382-383

102 Chatterjee S, Sengupta T, Majumder S, Majumder R. COVID-19: a probable role of the anticoagulant Protein $S$ in managing COVID-19-associated coagulopathy. Aging (Albany NY) 2020; 12(16):15954-15961
103 Ruzicka JA. Identification of the antithrombotic protein $\mathrm{S}$ as a potential target of the SARS-CoV-2 papain-like protease. Thromb Res 2020;196:257-259

104 Lippi G, Henry BM, Sanchis-Gomar F. Plasma antithrombin values are significantly decreased in coronavirus disease 2019 (COVID-19) patients with severe illness. Semin Thromb Hemost 2021;47(04):460-462

105 Ranucci M, Ballotta A, Di Dedda U, et al. The procoagulant pattern of patients with COVID-19 acute respiratory distress syndrome. J Thromb Haemost 2020;18(07):1747-1751

106 Han H, Yang L, Liu R, et al. Prominent changes in blood coagulation of patients with SARS-CoV-2 infection. Clin Chem Lab Med 2020;58(07):1116-1120

107 Gazzaruso C, Paolozzi E, Valenti C, et al. Association between antithrombin and mortality in patients with COVID-19. A possible link with obesity. Nutr Metab Cardiovasc Dis 2020;30(11): 1914-1919

108 Anaklı İ, Ergin Özcan P, Polat Ö, et al. Prognostic value of antithrombin levels in COVID-19 patients and impact of fresh frozen plasma treatment: a retrospective study. Turk J Haematol 2021;38(01):15-21

109 Liao D, Zhou F, Luo L, et al. Haematological characteristics and risk factors in the classification and prognosis evaluation of COVID-19: a retrospective cohort study. Lancet Haematol 2020;7(09):e671-e678

110 Gross O, Moerer O, Weber M, Huber TB, Scheithauer S. COVID-19associated nephritis: early warning for disease severity and complications? Lancet 2020;395(10236):e87-e88

111 Boscolo A, Spiezia L, Correale C, et al. Different hypercoagulable profiles in patients with COVID-19 admitted to the internal medicine ward and the intensive care unit. Thromb Haemost 2020;120(10):1474-1477

112 Levy JH, Sniecinski RM, Welsby IJ, Levi M. Antithrombin: antiinflammatory properties and clinical applications. Thromb Haemost 2016;115(04):712-728

113 Terpos E, Ntanasis-Stathopoulos I, Elalamy I, et al. Hematological findings and complications of COVID-19. Am J Hematol 2020;95 (07):834-847

114 Bharadwaj J, Jayaraman C, Shrivastava R. Heparin resistance. Lab Hematol 2003;9(03):125-131

115 Arachchillage DJ, Remmington C, Rosenberg A, et al. Anticoagulation with argatroban in patients with acute antithrombin deficiency in severe COVID-19. Br J Haematol 2020;190(05): e286-e288

116 Salem N, Atallah B, El Nekidy WS, Sadik ZG, Park WM, Mallat J. Thromboelastography findings in critically ill COVID-19 patients. J Thromb Thrombolysis 2021;51(04):961-965

117 Wright FL, Vogler TO, Moore EE, et al. Fibrinolysis shutdown correlation with thromboembolic events in severe COVID-19 infection. J Am Coll Surg 2020;231(02):193.e1-203.e1

118 Creel-Bulos C, Auld SC, Caridi-Scheible M, et al. Fibrinolysis shutdown and thrombosis in a COVID-19 ICU. Shock 2021;55 (03):316-320

119 Ibañez C, Perdomo J, Calvo A, et al. High D dimers and low global fibrinolysis coexist in COVID19 patients: what is going on in there? J Thromb Thrombolysis 2021;51(02):308-312

120 Collett LW, Gluck S, Strickland RM, Reddi BJ. Evaluation of coagulation status using viscoelastic testing in intensive care patients with coronavirus disease 2019 (COVID-19): an observational point prevalence cohort study. Aust Crit Care 2021;34 (02):155-159

121 Weiss E, Roux O, Moyer J-D, et al. Fibrinolysis resistance: a potential mechanism underlying COVID-19 coagulopathy. Thromb Haemost 2020;120(09):1343-1345

122 Tsantes AE, Frantzeskaki F, Tsantes AG, et al. The haemostatic profile in critically ill COVID-19 patients receiving therapeutic anticoagulant therapy: an observational study. Medicine (Baltimore) 2020;99(47):e23365 
123 Blasi A, von Meijenfeldt FA, Adelmeijer J, et al. In vitro hypercoagulability and ongoing in vivo activation of coagulation and fibrinolysis in COVID-19 patients on anticoagulation. J Thromb Haemost 2020;18(10):2646-2653

124 Kwaan HC, Lindholm PF. The central role of fibrinolytic response in COVID-19-a hematologist's perspective. Int J Mol Sci 2021;22 (03):1283

125 Grau GE, de Moerloose P, Bulla O, et al. Haemostatic properties of human pulmonary and cerebral microvascular endothelial cells. Thromb Haemost 1997;77(03):585-590

126 MacLaren R, Stringer KA. Emerging role of anticoagulants and fibrinolytics in the treatment of acute respiratory distress syndrome. Pharmacotherapy 2007;27(06):860-873

127 Whyte CS, Morrow GB, Mitchell JL, Chowdary P, Mutch NJ. Fibrinolytic abnormalities in acute respiratory distress syndrome (ARDS) and versatility of thrombolytic drugs to treat COVID-19. J Thromb Haemost 2020;18(07):1548-1555

128 Fujimoto H, Gabazza EC, Hataji O, et al. Thrombin-activatable fibrinolysis inhibitor and protein $C$ inhibitor in interstitial lung disease. Am J Respir Crit Care Med 2003;167(12):1687-1694

129 Sun W, Li ZR, Shi ZC, Zhang NF, Zhang YC. Changes in coagulation and fibrinolysis of post-SARS osteonecrosis in a Chinese population. Int Orthop 2006;30(03):143-146

130 Wiwanitkit V, ed. Thrombohemostatic disorder in new viral emerging diseases. In: Thrombohemostatic Disease Research. New York, NY: Nova Science Publishers; 2006:181-186

131 Hardy M, Michaux I, Lessire S, et al. Prothrombotic disturbances of hemostasis of patients with severe COVID-19: a prospective longitudinal observational study. Thromb Res 2021;197:20-23

132 Masi P, Hékimian G, Lejeune M, et al. Systemic inflammatory response syndrome is a major contributor to COVID-19-associated coagulopathy: insights from a prospective, single-center cohort study. Circulation 2020;142(06):611-614

133 Yang M, Ng MH, LiCK. Thrombocytopenia in patients with severe acute respiratory syndrome (review). Hematology 2005;10(02):101-105

134 Peiris JSM, Chu C-M, Cheng VC-C, et al; HKU/UCH SARS Study Group. Clinical progression and viral load in a community outbreak of coronavirus-associated SARS pneumonia: a prospective study. Lancet 2003;361(9371):1767-1772

135 Lee $\mathrm{N}$, Hui $\mathrm{D}$, Wu A, et al. A major outbreak of severe acute respiratory syndrome in Hong Kong. N Engl J Med 2003;348(20): 1986-1994

136 Zou Z, Yang Y, Chen J, et al. Prognostic factors for severe acute respiratory syndrome: a clinical analysis of 165 cases. Clin Infect Dis 2004;38(04):483-489

137 Tsang KW, Ho PL, Ooi GC, et al. A cluster of cases of severe acute respiratory syndrome in Hong Kong. N Engl J Med 2003;348(20): 1977-1985

138 Liu C-L, Lu Y-T, Peng M-J, et al. Clinical and laboratory features of severe acute respiratory syndrome vis-a-vis onset of fever. Chest 2004;126(02):509-517

139 Wang J-T, Sheng W-H, Fang C-T, et al. Clinical manifestations, laboratory findings, and treatment outcomes of SARS patients. Emerg Infect Dis 2004;10(05):818-824

140 Lang ZW, Zhang LJ, Zhang SJ, et al. A clinicopathological study of three cases of severe acute respiratory syndrome (SARS). Pathology 2003;35(06):526-531

141 Min C-K, Cheon S, Ha N-Y, et al. Comparative and kinetic analysis of viral shedding and immunological responses in MERS patients representing a broad spectrum of disease severity. Sci Rep 2016;6(01):25359

142 Ko J-H, Park GE, Lee JY, et al. Predictive factors for pneumonia development and progression to respiratory failure in MERSCoV infected patients. J Infect 2016;73(05):468-475

143 Memish ZA, Zumla AI, Al-Hakeem RF, Al-Rabeeah AA, Stephens GM. Family cluster of Middle East respiratory syndrome coronavirus infections. N Engl J Med 2013;368(26):2487-2494
144 Assiri A, McGeer A, Perl TM, et al; KSA MERS-CoV Investigation Team. Hospital outbreak of Middle East respiratory syndrome coronavirus. N Engl J Med 2013;369(05):407-416

145 Al-Tawfiq JA, Hinedi K, Abbasi S, Babiker M, Sunji A, Eltigani M. Hematologic, hepatic, and renal function changes in hospitalized patients with Middle East respiratory syndrome coronavirus. Int J Lab Hematol 2017;39(03):272-278

146 Liu Y, Sun W, Guo Y, et al. Association between platelet parameters and mortality in coronavirus disease 2019: retrospective cohort study. Platelets 2020;31(04):490-496

147 Zhang Y, Zeng X, Jiao Y, et al. Mechanisms involved in the development of thrombocytopenia in patients with COVID-19. Thromb Res 2020;193:110-115

148 Yang X, Yang Q Wang Y, et al. Thrombocytopenia and its association with mortality in patients with COVID-19. J Thromb Haemost 2020;18(06):1469-1472

149 Lippi G, Plebani M, Henry BM. Thrombocytopenia is associated with severe coronavirus disease 2019 (COVID-19) infections: a meta-analysis. Clin Chim Acta 2020;506:145-148

150 Jiang SQ, Huang QF, Xie WM, Lv C, Quan XQ. The association between severe COVID-19 and low platelet count: evidence from 31 observational studies involving 7613 participants. Br J Haematol 2020;190(01):e29-e33

151 Thachil J, Tang N, Gando S, et al. ISTH interim guidance on recognition and management of coagulopathy in COVID-19. J Thromb Haemost 2020;18(05):1023-1026

152 Thachil J. What do monitoring platelet counts in COVID-19 teach us? J Thromb Haemost 2020;18(08):2071-2072

153 Handtke S, Thiele T. Large and small platelets-(When) do they differ? J Thromb Haemost 2020;18(06):1256-1267

154 Amgalan A, Othman M. Exploring possible mechanisms for COVID-19 induced thrombocytopenia: unanswered questions. J Thromb Haemost 2020;18(06):1514-1516

155 Manne BK, Denorme F, Middleton EA, et al. Platelet gene expression and function in patients with COVID-19. Blood 2020;136(11): 1317-1329

156 Rapkiewicz AV, Mai X, Carsons SE, et al. Megakaryocytes and plateletfibrin thrombi characterize multi-organ thrombosis at autopsy in COVID-19: a case series. EClinicalMedicine 2020;24:100434

157 Iba T, Levy JH, Levi M, Connors JM, Thachil J. Coagulopathy of coronavirus disease 2019. Crit Care Med 2020;48(09): 1358-1364

158 Salamanna F, Maglio M, Landini MP, Fini M. Platelet functions and activities as potential hematologic parameters related to Coronavirus Disease 2019 (Covid-19). Platelets 2020;31(05):627-632

159 Zhang S, Liu Y, Wang X, et al. SARS-CoV-2 binds platelet ACE2 to enhance thrombosis in COVID-19. J Hematol Oncol 2020;13(01): 120

160 Chen Y, Wang J, Liu C, et al. IP-10 and MCP-1 as biomarkers associated with disease severity of COVID-19. Mol Med 2020;26(01):97

161 Chan AS, Rout A. Use of neutrophil-to-lymphocyte and platelet-tolymphocyte ratios in COVID-19. J Clin Med Res 2020;12(07):448-453

162 Eslamijouybari M, Heydari K, Maleki I, et al. Neutrophil-tolymphocyte and platelet-to-lymphocyte ratios in COVID-19 patients and control group and relationship with disease prognosis. Caspian J Intern Med 2020;11(Suppl 1):531-535

163 Zhong Q Peng J. Mean platelet volume/platelet count ratio predicts severe pneumonia of COVID-19. J Clin Lab Anal 2021; 35(01):e23607

164 He J, Wei Y, Chen J, Chen F, Gao W, Lu X. Dynamic trajectory of platelet-related indicators and survival of severe COVID-19 patients. Crit Care 2020;24(01):607

165 Canzano P, Brambilla M, Porro B, et al. Platelet and endothelial activation as potential mechanisms behind the thrombotic complications of COVID-19 patients. JACC Basic Transl Sci 2021:6(03):202-218 